\title{
超高層ビルを対象とした全館避難時のエレベーター利用に関する研究 STUDY ON EVACUATION USING ELEVATORS IN A HIGH-RISE BUILDING
}

\author{
中濱慎司*, 関澤 愛**, 池畠由華***, 野竹宏彰**** \\ Shinji NAKAHAMA, Ai SEKIZAWA, Yuka IKEHATA \\ and Hiroaki NOTAKE
}

\begin{abstract}
In many past fires, not a few people used elevators for their evacuation, although they were often told not to use elevators for fire evacuation. On the other hand, the number of people, who have difficulty to use stairs, has been larger year by year not only in usual buildings but also in high-rise buildings as well, since the aged people have been rapidly increasing along with improved accessibility for disabled people. Also, the potential demand of elevator use in evacuation from a high-rise building has been growing recently especially after the collapse of WTC towers on September 11 $1^{\text {th }}$ 2001. The evacuation using elevators in case of a fire is still a controversial issue, because the safe operation of elevators is not always secured during evacuation in a fire. In the context of this situation, we developed a simplified model to simulate the operation of multiple elevators for calculating evacuation time by elevators. And, we conducted some case studies with this elevator operation model to examine the feasibility and issues of elevator use for evacuation mainly from the viewpoint of its transportation efficiency of occupants rather than fire safety aspects during the operation.
\end{abstract}

\section{Keywords :Elevator, Stairs, Evacuation model, High-Rise Building, Total Evacuation エレベーター，階段，避難モデル，高層ビル，全館避難}

\section{1. 研究の背景と目的}

\section{1 エレベーター利用避難をめぐる動向}

わが国において，火災時における超高層ビルの避難計画は，従来 特別避難階段による避難が前提であり，エレベーター（以降， EV と記す）を利用した避難は考えられていない。また，EV の避難時 利用は法令上禁止されてはいないものの, 日本エレベーター協会等 の自主規制により利用を控えることが一般的である。しかしながら， 1996 年に発生した広島基町高層住宅火災 ${ }^{11}$ のように, 火元に近い部 分に居住していた人の半数以上が実際には避難時に $\mathrm{EV}$ を利用した 事例もあり，初期火災の段階で $\mathrm{EV}$ を用いて避難を行ったケースも 見受けられる。

一方で, 高齢者人口の急増, 障害を持つ人の社会参加の拡大, お よび一般建築へのアクセシビリティ改善などにより, 公共建築だけ でなく百貨店や高層事務所建築においても，車い寸利用者等の火炎 時に階段を利用して避難することが困難な人達が在館者の中に次第 に増えつつある。こうした背景の中で，日本建築学会に設置された 「避難安全のバリアフリーデザイン特別調查委員会」 ${ }^{2)}$ ，または， 東京消防庁の火災予防審議会人命安全対策部会での「高齢社会の到

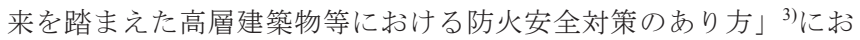
いて, 自力歩行困難者の避難支援手法として $\mathrm{EV}$ 利用の検討を行な う等, 徐々に避難時に EV を利用寸ることへの関心が高まっている。 国内外で, 特に $\mathrm{EV}$ 利用避難への関心が高くなった事例としては, 2001 年 9 月 11 日に発生した世界貿易センタービルへの飛行機衝突
によるビル崩壊が挙げられる。この事件以降，米国では超高層ビル であっても，従来のような火災階近辺の一時的かつ部分的な避難に 留まらず，スムーズな全館避難の要求が高まり，EV の緊急時避難 利用の検討が始められ，2004 年に NIST（米国標準技術研究所）と ASME（米国機械工学会）が協同でワークショップを開催し, 消防 隊専用の $\mathrm{EV}$ と在館者避難用 $\mathrm{EV}$ の災時の安全性と有効性につい て議論が行なわれた ${ }^{4)}$ 。これらの動きがもとになり，米国で最も普 及している建築基準である ICC（International Code Council）の IBC (International Building Code) 2009 年版において, 消防隊専用 EV の 技術基準と設置基準が定められた ${ }^{5)}$ 。さらに，420ft（約 128m）以上 の新築の高層ビルは 3 目の避難階段を設置せねばならないことに なったが，その一つを在館者用避難 $\mathrm{EV}$ に代替できる緩和規定を設 けており, 米国での新築の高層ビルでは今後在館者用避難 $\mathrm{EV}$ の設 置が増える可能性がある。

\section{2 既往の研究}

火災時における $\mathrm{EV}$ 利用避難を体系的に検討した例として，日本 建築学会 $\mathrm{EV}$ 利用避難特別研究委員会の指針案が挙げられる 6 。 この指針案では, $\mathrm{EV}$ を避難に利用するに当たっての要求性能が避 難計画，煙制御計画，運用面からまとめられ，病院を対象にケース スタディを実施している。しかし，この研究では介護が必要な患者 と管理側との対応に主眼を置いており，一般建物内での $\mathrm{EV}$ 避難を 対象としていないという課題がある。一般建物，特に超高層ビルを 対象とした $\mathrm{EV}$ 避難に関する検討として，河合等による $\mathrm{EV}$ 輸送能

\footnotetext{
* 大成建設技術センター 修士 (環境科学

** 東京理科大学 教授. 工博

*** 大成建設技術センター 博士 (工学)

**** 清水建設技術研究所 博士 (工学)
}

Taisei Technology Center, Taisei Corporation

Prof., Tokyo University of Science, Dr. Eng.

Taisei Technology Center, Taisei Corporation, Dr. Eng.

Institute of Technology, Shimizu Corporation, Dr. Eng. 
力算定 ${ }^{7)}$, 三浦等の $\mathrm{EV}$ 避難モデルの提案 ${ }^{8}$, Edwin R. Galea 等に よる超高層建物を対象とした避難モデルと運行方法の提案がある 9) 河合等による研究では, 高層住宅を対象に EV4 台（乗用 2 台, 非常用 2 台）を利用して, 自力歩行困難者がある一定割合居住して いると想定し, EVの輸送能力を算定している。この研究では, EV 避難モデルは避難階から EV のサービス階に停止し, 避難階まで再 び戻ってくるまでの一往復に掛かる時間の算定のみであり, 全館避 難を対象とした EV の運行方法による輸送能力の効果を分析するこ とは行っていない。三浦等の研究では, 53 階建ての超高層事務所ビ ルを対象に複数台の $\mathrm{EV}$ による移動を考慮した避難モデルを提案し ている。しかし，本モデルは複数台の $\mathrm{EV}$ 避難を扱えるモデルとし ているが，EV 避難の完了時間は単に 1 台の移動に台数分の能力を 単純に掛けたものであり, 個別の複数台の運行オペレーションを考 慮できないという課題がある。

Edwin R. Galea 等による研究では, 50 階建ての超高層事務所ビ ルを対象に, 避難者個々の移動と個々の $\mathrm{EV}$ 運行を両立させたモデ ルを提案している。この研究では, 運行パターンを 10 例取り上げ, スカイロビー形式が階段避難時間と比較して約 $50 \%$ の削減効果が あることを示している。しかし，この研究における計算対象の EV は乗用 $\mathrm{EV}$ のみであり, 多数ある乗用 $\mathrm{EV}$ を利用した場合の運行モ ードと避難完了時間の関係が主な焦点となっている。

\section{3 研究の目的}

わが国では，EV の避難時利用については検討が始まったばかり であり, 全館避難時を対象とした EV 避難のあり方については充分 に検討されていないのが現状である。しかし, わが国では超高層ビ ルには非常用 EV が設置されており, 消防隊の利用を前提としたも のではあるが, 火災時の避難あるいは救助目的の利用が可能である。 その一方で，超高層ビルにある既存施設としての非常用 EV を火災 避難に利用した場合に, 特別避難階段のみ利用の避難と比べて $\mathrm{EV}$ 利用避難のパターンがどの程度有効であるかを調べた研究はこれま でなかった。

本研究では, 超高層ビルにおける全館避難時に, 特別避難階段の み利用の避難に比べて種々の $\mathrm{EV}$ 利用避難のパターンがどの程度有 効であるかを調べることを目的として, 超高層ビルを対象にケース スタディを行った。 EV 利用避難の有効性は, 全館避難時における 特別避難階段と乗用または非常用 $\mathrm{EV}$ による避難時間の比較により 検討した。そして，ケーススタディを実行するに当たり， EV 利用 避難モデルの開発 10)や $\mathrm{EV}$ 乗降時の流動係数の調查を実施した。

\section{2. $E V$ 利用避難の運行方法に関する比較検討ケーススタディ}

\section{1 ケーススタディの設定条件}

\section{(1) 検討対象建物}

$\mathrm{EV}$ 利用避難における運行方法の比較検討のケーススタディを行 うにあたり，実存する超高層事務所ビルを参考として検討対象とな る超高層ビルを設定した。検討対象建物の平面図と $\mathrm{EV}$ 構成を図 1 に示す。

検討対象建物は, $1 \mathrm{~F}$ を避難階として $57 \mathrm{~F}$ を最上階, 階高は $3.65 \mathrm{~m}$ (1F のみ $7.0 \mathrm{~m}$ ) とした。基準階床面積は $2,629 \mathrm{~m}^{2}$ (内 $1,680 \mathrm{~m}^{2} か ゙$ 事務 所用途) で, コアに乗用 $\mathrm{EV}$ や非常用 $\mathrm{EV}$, 特別避難階段が配置され たセンターコア形式とした。避難階である $1 \mathrm{~F}$ を除き, 各階の在館
者数は, 事務所面積 $1,680 \mathrm{~m}^{2} /$ 階に在館者密度 0.125 人 $/ \mathrm{m}^{2}$ を掛けた 210 人と設定し, 全館では 11,760 人 (56 階層分) の在館者となる。 また, $\mathrm{EV}$ 構成は図 1 に示すようにサービス階が異なる 4 つの乗用 $\mathrm{EV}$ バンクと，全ての階に停止する 2 つの非常用 $\mathrm{EV}$ とした。

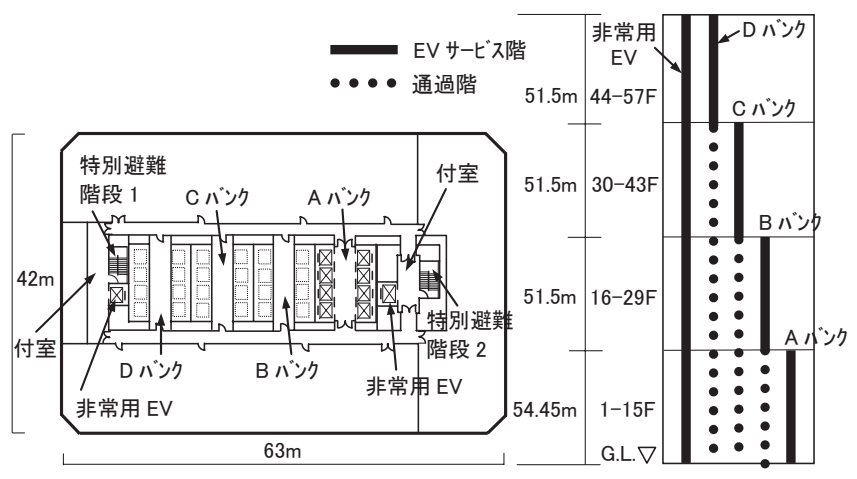

図 1 検討対象建物の平面図と $\mathrm{EV}$ 構成

\section{(2) EV および特別避難階段の設定条件}

乗用 $\mathrm{EV}$ および非常用 $\mathrm{EV}$, さらに特別避難階段の設定条件を, 表 1 および表 2 に示す。なお，これら設定条件も実存する超高層事 務所ビルを参考に設定した。

表 1 EV の設定条件

\begin{tabular}{|c|c|c|c|c|c|c|c|}
\hline & 単位 & Aバンク & Bバンク & Cバンク & Dバンク & 非常用EV \\
\hline \multicolumn{2}{|c|}{ サービス階 } & 階 & $1 \sim 15$ & $\mid 16 \sim 29$ & $30 \sim 43$ & \begin{tabular}{|l|}
$44 \sim 57$ \\
\end{tabular} & $1 \sim 57$ \\
\hline \multicolumn{2}{|c|}{ サービス階人数 } & 人 & 2940 & 2940 & 2940 & 2940 & 11760 \\
\hline \multicolumn{2}{|l|}{ EV台数 } & 台 & 8 & 8 & 8 & 8 & 2 \\
\hline \multicolumn{2}{|c|}{$\mathrm{EV}$ 収容人数 } & 人/台 & 22 & 22 & 22 & 22 & 32 \\
\hline \multicolumn{2}{|c|}{ 定格速度 } & $\mathrm{m} / \mathrm{s}$ & 4 & 5 & 6 & 7 & 3 \\
\hline \multicolumn{2}{|l|}{ 加速度 } & $\mathrm{m} / \mathrm{s}^{2}$ & 0.7 & 0.7 & 0.7 & 0.7 & 0.7 \\
\hline \multicolumn{2}{|l|}{ 減速度 } & $\mathrm{m} / \mathrm{s}^{2}$ & -0.7 & \begin{tabular}{|c|}
-0.7 \\
\end{tabular} & -0.7 & \begin{tabular}{|l|}
-0.7 \\
\end{tabular} & -0.7 \\
\hline \multicolumn{2}{|l|}{ EV扉幅 } & $\mathrm{m}$ & 1.1 & 1.1 & 1.1 & 1.1 & 1.9 \\
\hline \multicolumn{2}{|c|}{ EV扉 開時間 } & $\mathrm{s}$ & 1.5 & 1.5 & 1.5 & 1.5 & 1.5 \\
\hline \multicolumn{2}{|c|}{ 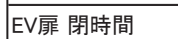 } & $\mathrm{s}$ & 1.5 & 1.5 & 1.5 & 1.5 & 1.5 \\
\hline \multirow[t]{2}{*}{ 流動係数 } & 乗車 & 人 $/ \mathrm{m} / \mathrm{s}$ & 1.07 & 1.07 & 1.07 & 1.07 & 1.07 \\
\hline & 降車 & 人 $/ \mathrm{m} / \mathrm{s}$ & 1.22 & 1.22 & 1.22 & 1.22 & 1.22 \\
\hline
\end{tabular}

表 2 特別避難階段の設定条件

\begin{tabular}{|c|c|r|r|}
\hline & 単位 & 特別避難階段 1 & 特別避難階段 2 \\
\hline 最大水平移動距離 & $\mathrm{m}$ & 44.0 & 44.0 \\
\hline 水平速度 & $\mathrm{m} / \mathrm{s}$ & 1.0 & 1.0 \\
\hline 最大垂直移動距離 & $\mathrm{m}$ & 207.75 & 207.75 \\
\hline 階段降下速度 & $\mathrm{m} / \mathrm{s}$ & 0.2 & 0.2 \\
\hline 階段幅員 & $\mathrm{m}$ & 1.2 & 1.2 \\
\hline 出入口有効幅員 & $\mathrm{m}$ & 1.08 & 1.08 \\
\hline 階段流動係数 & 人/ $/ \mathrm{m} / \mathrm{s}$ & 1.3 & 1.3 \\
\hline 出入口流動係数 & 人 $/ \mathrm{m} / \mathrm{s}$ & 1.5 & 1.5 \\
\hline
\end{tabular}

$\mathrm{EV}$ の台数は, 乗用 $\mathrm{EV}$ が設置される $\mathrm{A} \sim \mathrm{D}$ バンクでは各 8 台, 非常用 $\mathrm{EV}$ は 2 台, 合計 34 台とした。また, EV 利用のサービス階 は，A〜D バンクにおいて $1 \mathrm{~F}$ および 14 階層分，非常用 $\mathrm{EV}$ は 1 $57 \mathrm{~F}$ の全ての階とした。これより, $\mathrm{A} \sim \mathrm{D}$ バンクでは, $\mathrm{EV}$ 利用可能 人数が 2,940 人, 非常用 $\mathrm{EV}$ では 11,760 人となる。

$\mathrm{EV}$ カゴの収容人数は, $\mathrm{A} \sim \mathrm{D}$ バンクの乗用 $\mathrm{EV}$ で 22 人, 非常用 $\mathrm{EV}$ で 32 人の設定とした。また, 乗用 $\mathrm{EV} の$ 定格速度は高層階を步 
ービス階とするバンクほど速い值となり, A バンクでは $4 \mathrm{~m} / \mathrm{s}, \mathrm{D}$ バ ンクでは $7 \mathrm{~m} / \mathrm{s}$ とした。非常用 $\mathrm{EV}$ は実状に合わせて, 定格速度を

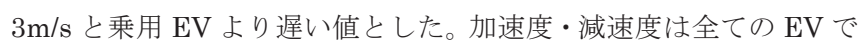
同じである。扉幅は, 乗用 $\mathrm{EV}$ で $1.1 \mathrm{~m}$, 非常用 $\mathrm{EV}$ で $1.9 \mathrm{~m}$ とした。

$\mathrm{EV}$ の乗降時間の算定には, EV 扉の流動係数が必要となるが, $\mathrm{EV}$ 内部は閉鎖空間であるため, 通常の建物扉の流動係数と異なる と考えられる。そこで, $\mathrm{EV}$ 屝の流動係数は, $\mathrm{EV}$ 利用者の乗降調査 に基づいて設定した。乗降調査の詳細は 2.4 節で示す。

特別避難階段は 2 ケ所設置され，設定条件は同じである。階段内 の移動は垂直移動として表し, 最大垂直移動距離を $207.75 \mathrm{~m}$, 階段 内の降下速度を $0.2 \mathrm{~m} / \mathrm{s}$ とした。また, 階段内および出入口での流 動係数をそれぞれ 1.3 人 $/ \mathrm{m} / \mathrm{s} ， 1.5$ 人 $/ \mathrm{m} / \mathrm{s}$ とした。

\section{(3) 運行方法}

運行方法は 3 つの避難手段 (乗用 $\mathrm{EV}$, 非常用 $\mathrm{EV}$, 特別避難階段) を組合せ，火災階や $\mathrm{EV}$ の移動優先階に基づき，大きく以下の 4 ケ 一スを設定した。各ケースの計算条件を表 3 に示す。なお, 各ケー スにおいて火災階を指定しており，火災階を最優先に $\mathrm{EV}$ 利用する べきであるが，本ケーススタディでは火災による煙流動や熱による 影響は考慮せず，運行方法や避難手段による避難完了時間の違いを 分析するため, $\mathrm{EV}$ の運行方法は最上階優先をベースとした。

\section{(1)ケース 1：各避難手段による避難完了時間の比較}

ケース 1 では, 対象建物の中で最も高層に位置する $\mathrm{D}$ バンクサー ビス階を計算対象として取り上げ，バンクに滞在する在館者が乗用 $\mathrm{EV}$, 非常用 $\mathrm{EV}$, 特別避難階段を利用した場合の避難完了時間を計 算する。なお, 乗用 EV のサービス階の最下階 $(44 \mathrm{~F})$ で火災が発 生したと想定寸る。また参考ケースとして, 乗用 $\mathrm{EV}$ や非常用 $\mathrm{EV}$ を利用せず, $\mathrm{A} \sim \mathrm{D}$ バンクのサービス階に滞在する全ての在館者が， 特別避難階段で全館避難した検討も比較対象とする。

\section{(2)ケース 2: 非常用 EV の運行方法による影響}

ケース 2 は, ケース 1 と同様に D バンクサービス階を計算対象に 取り上げ，D バンクサービス階での避難方法を以下の 3 パターン想 定することで, 非常用 EV の運行方法や到着階の違いによる影響を 把握する。

\section{1）最上階優先運行}

この運行方法は, 非常用 $\mathrm{EV}$ を D バンクサービス階の最上階から 優先的に移動させて順次下層階へと移動させる。なお, ケース 1 に おける非常用 EV での D バンクサービス階の条件と同じである。

\section{2) $E V$ 火災階および直上 $2 F$ 優先運行}

この運行方法は, 非常用 EV を火災階最優先として移動させる。 火災階の避難が完了した後, 次の移動優先階を直上 2 階層として非 常用 $\mathrm{EV}$ が移動する。なお, これらの階の在館者が全て避難完了し た場合, 非常用 EV の優先階は D バンクサービス階の内, 最上階か ら順次下階一と移行する。

\section{3）中間避難階移動}

この運行方法は，火災階直下階（43F）を中間避難階と設定し， $\mathrm{D}$ バンクサービス階の避難者を一旦中間避難階まで避難させ，その 後 2 つの特別避難階段を利用して $1 \mathrm{~F}$ まで避難させる。

\section{(3)ケース 3 : 非常用 EV のサービス階の限定による影響}

ケース 3 では, 建物全館（1～57F）を計算対象として取り上げ, 非常用 $\mathrm{EV}$ を数フロア通過させるスキップ運転をした場合の避難時
間に及ぼす影響を検討した。非常用 EV の通過する階数を 1 ～13 ま で変化させて, 非常用 $\mathrm{EV}$ の乗降回数や利用者数を限定させた場合 の避難完了時間への影響を, 特別避難階段による避難完了時間との 比較から把握する。例えば，通過階数を 1 とした場合のサービス階 数は 27 , 通過階数を 13 とした場合のサービス階数は 5 となる。な お，非常用 EV のサービス対象階から外れた階は特別避難階段を利 用して避難する。

\section{(4)ケース 4: 非常用 EV の利用率による影響}

超高層ビルにおいて，非常用 $\mathrm{EV}$ をより現実的なものにするため には，非常用 EV2 台の内， 1 台は避難用，残りの 1 台を消防隊専用 として利用することが考えられる。さらに，全ての在館者を対象と 寸るのではなく，限定的な利用による避難完了時間の短縮が図れる と考えられる。

そこで, ケース 4 では各階の在館者数の内, 非常用 $\mathrm{EV}$ の利用人 数を $10 \%$ 刻みで 0 〜 $100 \%$ に変更した場合の影響を，特別避難階段 による避難完了時間との比較から把握する。

表 3 各ケースの計算条件

\begin{tabular}{|c|c|c|c|c|c|c|c|}
\hline \multirow{2}{*}{ ケース } & \multirow{2}{*}{ 火災階 } & \multirow{2}{*}{$\begin{array}{c}\text { 計算対象 } \\
\text { バンクク }\end{array}$} & \multirow{2}{*}{ 避難手段* } & \multirow{2}{*}{$\begin{array}{l}\text { EV台数 (台), } \\
\text { 階段数(䓢所) }\end{array}$} & \multicolumn{2}{|c|}{ EV運行方法 } & \multirow{2}{*}{$\begin{array}{l}\text { 利用者数 } \\
\text { (人) }\end{array}$} \\
\hline & & & & & 優先階 & 停止階(階) & \\
\hline \multirow{4}{*}{ No. 1} & \multirow{4}{*}{ 44階 } & \multirow{3}{*}{ D } & 非EV & 2 & 最上階優先 & $1,44 \sim 57$ & 2,940 \\
\hline & & & 乗用EV & 8 & 最上階優先 & $1,44 \sim 57$ & 2,940 \\
\hline & & & 特避 & 2 & - & - & 2,940 \\
\hline & & $A \sim D$ & 特避 & 2 & - & - & 11,760 \\
\hline \multirow{3}{*}{ No.2 } & \multirow{3}{*}{ 44階 } & \multirow{3}{*}{ D } & 非EV & 2 & 最上階優先 & $1,44 \sim 57$ & 2,940 \\
\hline & & & 非EV & 2 & $\begin{array}{l}\text { 火災階および } \\
\text { 直上2階優先 }\end{array}$ & $1,44 \sim 57$ & 2,940 \\
\hline & & & $\begin{array}{l}\text { 非EV } \\
\text { +特避 }\end{array}$ & $\begin{array}{l}\text { 非EV } 2 \\
\text { 特避 } 2\end{array}$ & 最上階優先 & $\begin{array}{c}\text { 44〜 57, } \\
\text { 43階から特避 }\end{array}$ & 2,940 \\
\hline \multirow{2}{*}{ No. 3} & \multirow{2}{*}{ 2階 } & \multirow{2}{*}{$A \sim D$} & 非EV & 2 & 最上階優先 & 各階 13階層毎 & $840 \sim 5,880$ \\
\hline & & & 特避 & 2 & - & - & $5,880 \sim 10,920$ \\
\hline \multirow{2}{*}{ No.4 } & \multirow{2}{*}{ 2階 } & \multirow{2}{*}{$A \sim D$} & 非EV & 1 & 最上階優先 & $1 \sim 57$ & $0 \sim 11,760$ \\
\hline & & & 特避 & 2 & - & - & $0 \sim 11,760$ \\
\hline
\end{tabular}

\section{2. $2 \mathrm{EV}$ 利用避難モデルの概要}

今回のケーススタディを実施するにあたり, 乗用 $\mathrm{EV}$ ，非常用 $\mathrm{EV}$ の両方を含めた $\mathrm{EV}$ 利用避難の全館避難時間を算出するための $\mathrm{EV}$ 利用避難モデルを開発した。以下にその概要を示す。

(1) 前提条件および計算フロー

\section{(1)前提条件}

本研究で開発した $\mathrm{EV}$ 利用避難モデルは, 以下の前提条件に基づ

き，EV を避難に利用した場合の避難完了時間を算出する。

・EVの運行に際し，火災や煙の影響は受けない。

・各階の $\mathrm{EV}$ ホールまたは非常用 $\mathrm{EV}$ 兼用付室に滞在する在館者 の人数は事前に把握されている。

・全ての EV は避難階（1F）から移動を開始し，各 EV に設定さ れた目的階へ移動を開始する。

・ EV が満員の場合には $1 \mathrm{~F}$ 一直行し, カゴ内の利用者を全て降ろ す。その後, EVは次の目的階一移動する。

・ $\mathrm{EV}$ の収容人数が満員でない場合は $1 \mathrm{~F}$ に直行せず, 次の目的階 に移動する。

(2)計算フロー

$\mathrm{EV}$ 利用避難モデルの計算フローを図 2 に示す。計算フローは図 2 
に示すように大きく 4 ステップ (STEP) から構成される。以下, 各 STEP の概要を示す。

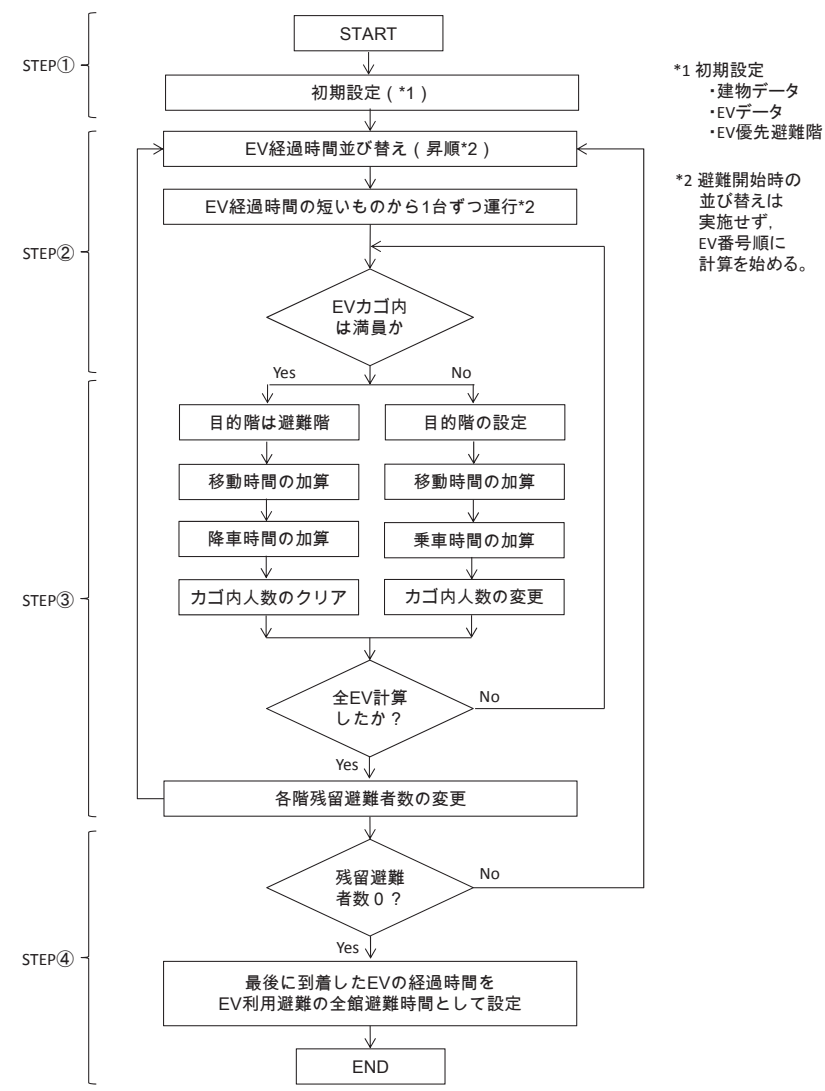

図 $2 \mathrm{EV}$ 利用避難モデルの計算フロー

\section{STEP(1) 初期設定データの読み込み}

ここでは, EV 利用避難による避難完了時間を計算する条件を設 定する。条件の設定としては, 建物側のデータと $\mathrm{EV}$ 側のデータに 分類される。建物側のデータとしては, 各階において階高, 滞在人 数, $\mathrm{EV}$ を優先的に移動させる順位を設定する。なお, $\mathrm{EV}$ の優先移 動階の設定を特にしていない場合, 最上階から順次下の階に優先順 位が設定される。 EV 側のデータとしては, 各 EVにおいて EV カ ゴの収容人数, 定格速度, 加減速度, 扉開口幅, $\mathrm{EV}$ 扉の開閉時間, 乗車および降車時の流動係数を設定する。

\section{STEP(2) EV 経過時間の並び替えおよび各 EV の移動目的階の設定}

本 $\mathrm{EV}$ 利用避難モデルの特徵は，同じ $\mathrm{EV}$ バンク内にある $\mathrm{EV} の$ 複数台の運行を計算することが可能な点である。本モデルでは, EV が移動開始階から移動目的階に到達して乗降が完了した時点で, 各 $\mathrm{EV}$ の所要時間を相互比較し, その所要時間が短い $\mathrm{EV}$ から移動計 算を優先させるロジックで次のステップでの移動計算順位を決定づ ける。そして, EV カゴ内が満員の場合, 目的階は避難階 $(1 \mathrm{~F})$ と なり, 満員でない場合は初期設定された移動優先階を目的階とする。 なお, 既に在館者が居ない優先階には移動せず, 次の順位の階に移 動するように設定をしている。また, EV 利用避難の開始時では, $\mathrm{EV}$ は全て避難階 $(1 \mathrm{~F})$ に着床しているものとし, 計算の順番も $\mathrm{EV}$ 番号順に計算される。

STEP(3) 各 EV の移動時間および乗降時間の計算
移動目的階の設定後, 各 EVはある一定の加速度で目的階に向け て移動を開始する。そして, 移動距離に応じて $\mathrm{EV}$ は定格速度で移 動し, さらに減速して目的階に到着する。そして, 目的階が避難階 では避難者は降車し，その他の階の場合は $\mathrm{EV}$ カゴ内に乗車する。 STEP(4) EV 利用による避難完了時間の計算

STEP(1)から (3)の計算が行われた後, 最後の EV 利用者が避難階 で $\mathrm{EV}$ カゴから降車し, $\mathrm{EV}$ 屝が閉まった時点で $\mathrm{EV}$ 利用避難の計 算は完了寸る。そして, 各 $\mathrm{EV}$ の中で最も時間が掛かった避難完了 時間を $\mathrm{EV}$ 利用による避難完了時間とする。

\section{（2）移動時間の算定}

今回開発した $\mathrm{EV}$ の移動モデルは， $\mathrm{EV}$ の定格速度への到達状況 に応じて 2 パターンに分類される。図 3 と図 4 に $\mathrm{EV}$ の移動モデル の概念図を示す。

図 3 は, EV が移動開始階から移動目的階までの間に, 加速段階, 定速段階, 減速段階の 3 つの段階に至る場合の移動速度の時間変化 を示したものである。一方，移動開始階から移動目的階までの垂直 移動距離が短い場合, 図 4 に示すように EV が定格速度に達する前 に $\mathrm{EV}$ は減速移動をするモデルとした。なお，本モデルでは加速度 及び減速度を一定值と設定し, 定速速度は $\mathrm{EV}$ バンクに応じて変更 させた。

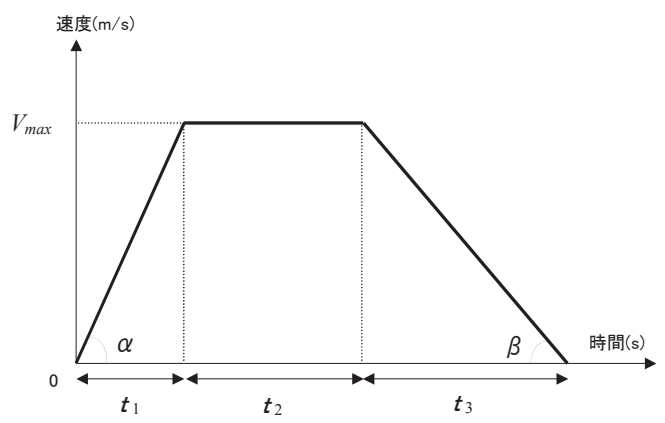

図 3 定速移動がある $\mathrm{EV}$ 移動モデル

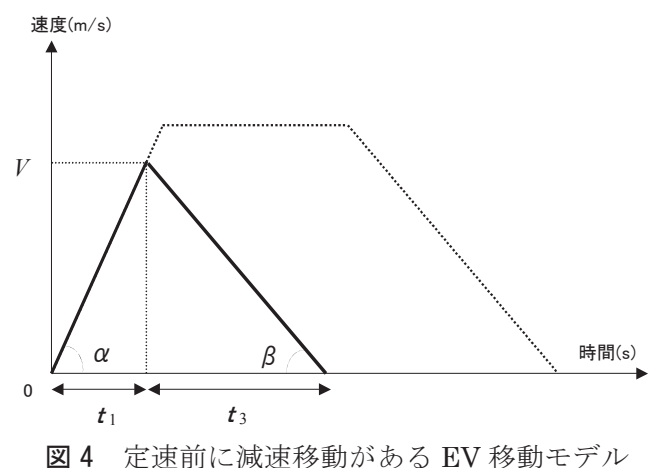

本 $\mathrm{EV}$ 利用避難モデルでは，移動開始階から移動目的階までに移 動する時間を, 上述のように加速段階, 定速段階, 減速段階に各々 分けて算出する。そして, 最後の $\mathrm{EV}$ 利用者が避難階に到着するま でこれら移動時間を加算する。EV の移動時間に関する算定式を式 1 ～7 に示す。なお，式中の記号の意味は文末に示す。

式 1 は, ある 1 台の $\mathrm{EV}$ が移動を開始して目的階までに移動する までの時間を表す。この時間は, $\mathrm{EV}$ の加速段階 $t_{1}$, 定速移動の段 階 $t_{2}$, 定速から減速に至る段階 $t_{3}$ を加算して求められる。そして, 各段階の時間は, 移動開始から移動目的階までの距離算定式 (式 5), 
定格速度の算定式（式 6) を用いることで，式 $2 \sim 3$ で表される。な お, 図 4 に示寸ように EV が定速に達する前に減速段階に移行する 場合，定速段階の移動時間の算定式（式 3) は 0 として扱われる。 これら移動開始階から移動目的階までの移動時間の計算を, 各 $\mathrm{EV}$ に対して建物の在館者が全て避難完了するまで繰り返し計算を行う。

$$
t_{\text {move }}=t_{1}+t_{2}+t_{3}=\frac{V_{\max }}{\alpha}+\frac{\left(L-\frac{\left(V_{\max }\right)^{2}}{2 \alpha}-\frac{\left(V_{\max }\right)^{2}}{2 \beta}\right)}{V_{\max }}+\frac{V_{\max }}{\beta}(1)
$$$$
\text { ここで, }
$$$$
t_{1}=\frac{V_{\max }}{\alpha}
$$

$$
t_{2}=\frac{\left(L-\frac{\left(V_{\max }\right)^{2}}{2 \alpha}-\frac{\left(V_{\max }\right)^{2}}{2 \beta}\right)}{V_{\max }}
$$

$t_{3}=\frac{V_{\max }}{\beta}$

$L=\frac{1}{2} \alpha t_{1}^{2}+V_{\max } t_{2}+\frac{1}{2} \beta t_{3}^{2}$

$V_{\text {max }}=\alpha t_{1}=\beta t_{3}$

\section{（3） EV 乗降時間の算出}

用語の定義として， EV 扉が開閉して避難者が $\mathrm{EV}$ 一流入または 流出に要する時間をそれぞれ乗車時間, 降車時間とし, その合計值 を乗降時間とする。

$\mathrm{EV}$ が移動を開始して目的階に到着し, $\mathrm{EV}$ 扉が開き $\mathrm{EV}$ 利用者が 乗車して扉が閉まるまでの時間を式 $7, \mathrm{EV}$ 扉が開き $\mathrm{EV}$ 利用者が降 車して扉が閉まるまでの時間を式 8 に示す。これら EV の乗降時間 は, 建物の在館者が全て避難完了寸るまで, 各 EV に乗降がある度 に計算が行われる。

$$
\begin{gathered}
t_{\text {flow_in }}=t_{\text {open }}+t_{\text {close }}+\frac{P_{\text {in }}}{W_{D} N_{\text {in }}} \\
t_{\text {flow_out }}=t_{\text {open }}+t_{\text {close }}+\frac{P_{\text {out }}}{W_{D} N_{\text {out }}}
\end{gathered}
$$

\section{3 階段利用避難モデルの概要}

\section{(1) 前提条件}

階段避難モデルは, 前述した EV 利用避難モデルとは別に Excel ベースで構築し, 特別避難階段を利用した場合の避難完了時間の算 定が行える。以下にモデルの前提条件を示す。

・階段内は火災や煙の影響は受けない。

・避難者は健常者と自力歩行困難者といった属性は考慮しない。

・避難開始時間は各階全て同時（0 秒で開始）とする。

・居室から階段室への移動は考慮しない。

・階段内の避難者と付室から階段室一流入しょうとする避難者と の合流や階段内の滞留密度による歩行速度変化は考慮せず, 一 定とする。

(2) 算定式
特別避難階段による避難完了時間の算定式を式 9 に示す。なお, 階段内の移動は垂直移動で表すものとし, 垂直移動距離と避難者の 垂直移動速度から時間が算定される。全館避難完了時間は, $2 \mathrm{~F}$ から 避難階（1F）までの垂直移動時間と，階段内の流出時間または $1 \mathrm{~F}$ の階段扉での流出時間の最大值との合計，さらに最上階からの移動 距離時間を比較して, その最大值とした。

$$
t_{\text {stairs }}=\max \left(\frac{L_{s}}{V_{s}}, \frac{L_{2 F->1 F}}{V_{s}}+\max \left(\frac{\sum_{i=2}^{n} P_{i}}{N_{\text {stairs }} \cdot W_{\text {stairs }}}, \frac{\sum_{i=2}^{n} P_{i}}{N_{\text {exit }} \cdot W_{\text {exit }}}\right)\right)
$$

\section{2. $4 \mathrm{EV}$ 乗降の流動係数に関する調査}

\section{(1) 調査目的}

$\mathrm{EV}$ 利用避難モデルでは，EV 乗降時間を式 7,8 により算出する。 しかし，EV 扉の場合，通常の建物出入口扉とは異なり，EVの内部 が閉鎖空間であるため, EV 内の滞留密度により流動係数が異なる と考えられる。そこで，EV への乗車および降車時の流動係数を得 るために, EV 利用者の乗降調査を実施した。

\section{(2) 調査概要}

$\mathrm{EV}$ 利用者の乗降調査は，実在する超高層事務所ビルに設置され た乗用 $\mathrm{EV}$ を対象とした。調查対象の $\mathrm{EV}$ バンクの平面図を図 5, $\mathrm{EV}$ 仕様を表 4 に示す。

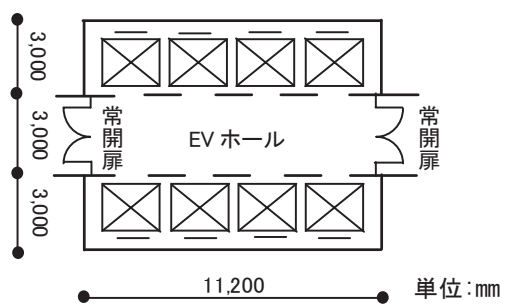

図 5 調查対象の $\mathrm{EV}$ バンク平面図

表 4 調查対象の $\mathrm{EV}$ 仕様

\begin{tabular}{|c|l|}
\hline 用途 & 乗用 \\
\hline 容量 & $1,450 \mathrm{~kg}$ 最大定員22名 \\
\hline 速度 & $4 \mathrm{~m} / \mathrm{s} \sim 7 \mathrm{~m} / \mathrm{s}$ \\
\hline かご内法 & 間口 $1,870 \mathrm{~mm} \times$ 奥行 $2,100 \mathrm{~mm}$ \\
\hline 出入口 & 幅 $1,100 \mathrm{~mm} \times$ 高さ2,100mm \\
\hline 戸形式 & 二枚戸中央開き \\
\hline
\end{tabular}

なお，調查の時間帯は多くの $\mathrm{EV}$ 利用者が見込まれ，かつ利用者 の乗降が一定方向になる出勤時および昼食時を対象とした。調查方 法の概要を以下に示す。

・調查日時： 2007 年 4 月 6 日(金) 11:45 12:15，17:30 18:00 2007 年 4 月 9 日(月) $\quad 8: 20 \sim 9: 15,11: 45 \sim 12: 45$

・調查場所 : 超高層事務所ビル内の乗用 $\mathrm{EV}$

$$
1 \mathrm{~F}, 6 \mathrm{~F} \text { (食堂階) }, 17 \sim 31 \mathrm{~F} \text { (乗車の夕調查) }
$$

・調查方法 : EV への乗降者人数, およびストップウォッチにより $\mathrm{EV}$ 利用者が $\mathrm{EV}$ 扉を通過する時間を計測した。

\section{(3) 調査結果}

乗降時の流動係数と EV カゴ内密度の関係を図 6 および図 7 に示 す。なお, 図 6 と図 7 の $\mathrm{EV}$ 内密度は, 乗車時では各階での乗車前 
に $\mathrm{EV}$ カゴ内に乗車している利用者の密度を示し, 降車時では降車 開始時点に EV カゴ内に滞在する利用者の密度を示す。

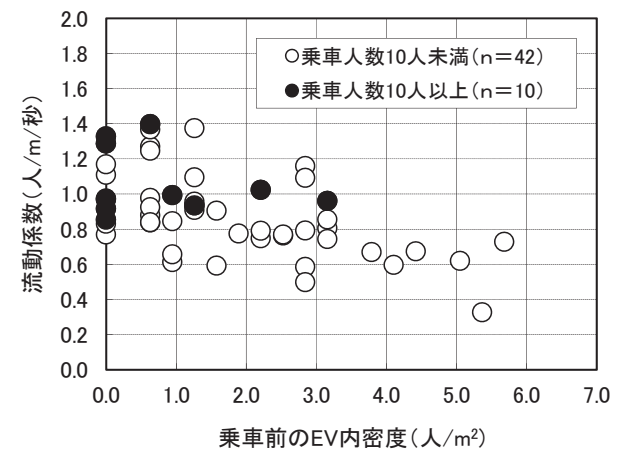

図 6 乗車時の流動係数と $\mathrm{EV}$ 内密度との関係

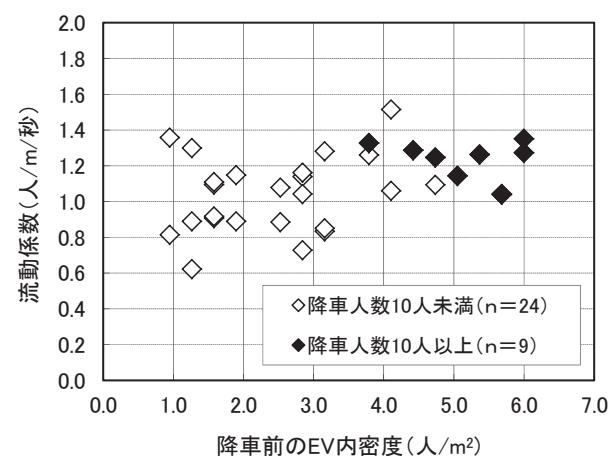

図 7 降車時の流動係数と $\mathrm{EV}$ 内密度との関係

乗車時の流動係数と $\mathrm{EV}$ 内密度との関係（図 6) をみると，乗車 時の流動係数にばらつきも見られるが， $\mathrm{EV}$ 内密度が大きくなると 流動係数が小さくなる傾向がみられた。Fruin によると一人あたり の面積が $0.32 \mathrm{~m}^{2} /$ 人 $\left(3.12\right.$ 人 $\left./ \mathrm{m}^{2}\right)$ に達すると, $\mathrm{EV}$ カゴ内の人は混 雑を感じると示されており ${ }^{11)}$, 本調査でも 3 人 $/ \mathrm{m}^{2}$ を超えたあたり から減少の度合いが大きくなる傾向がみられた。一度の乗車人数が 10 人以上のケースに限定した場合（図 6 の)，流動係数は $0.8 \sim$ 1.4 人 $/ \mathrm{m} / \mathrm{s}$ の範囲に分布し, 流動係数の平均值は 1.07 人 $/ \mathrm{m} / \mathrm{s}$ となっ た。乗車時の流動係数が, 避難計算で用いられる流動係数 1.5 人 $/ \mathrm{m} / \mathrm{s}$ より值が低くなった理由として, $\mathrm{EV}$ カゴ内が閉鎖空間であり, $\mathrm{EV}$ 利用者が $\mathrm{EV}$ カゴ内の空いたスペースをみつけて乗車するためと考 えられる。

降車時の流動係数と EV 内密度との関係（図 7）をみると, 流入 時と同様に EV 内密度が大きくなると流動係数がやや高くなる傾向 がみられた。しかし, 乗車時と比較すると密度の影響は小さく, 大 部分のデータが $0.8 \sim 1.4$ 人 $/ \mathrm{m} / \mathrm{s}$ の範囲に分布している。一度の降車 人数が 10 人以上のケースに限定した場合（図 7 の）の流動係数 は $1.0 \sim 1.4$ 人 $/ \mathrm{m} / \mathrm{s}$ であり，その平均值は 1.22 人 $/ \mathrm{m} / \mathrm{sec}$ となった。

降車時の流動係数が乗車時より大きい值となった理由として, EV 内に乗車する場合, EV カゴ内の閉じた空間に順次利用者が入り込 むのに対し, $\mathrm{EV}$ から流出する場合は $\mathrm{EV}$ ホールにある程度の移動 空間が確保されているためと考えられる。 EV 利用避難モデルでは, 上記調査で得た乗降時の流動係数の平均值を, モデル内の設定值と して用いることとした。

\section{5 計算結果と考察}

(1)ケース 1: 各避難手段による避難完了時間の比較

$\mathrm{D}$ バンク $\mathrm{EV}$ サービス階の滞在人数 2,940 人が, 非常用 $\mathrm{EV}$, 乗 用 $\mathrm{EV}$, 特別避難階段を利用した場合の避難完了時間の比較を図 8 に示す。図 8 より，D バンクサービス階での非常用 EV による避難 完了時間は 7,722 秒, 乗用 $\mathrm{EV}$ では 1,943 秒, 特別避難階段では 1,027 秒となった。今回の条件設定においては，D バンクサービス階の在 館者全てを EV で避難させるのではなく, 特別避難階段を利用した 方が早く避難が完了寸る結果となった。なお，全館の避難者 11,760 人が特別避難階段を利用した場合の全館避難完了時間は 3,805 秒と なり，D バンクサービス階の夕非常用 $\mathrm{EV}$ を利用して避難をした場 合の約半分の值となった。非常用 $\mathrm{EV}$ は乗用 $\mathrm{EV}$ と比較して, 付室 の設置等の火災対策が取られているが，定格速度が遅いために全館 の在館者を利用対象とした場合, 避難完了時間が非常に長くなるこ とが分かった。

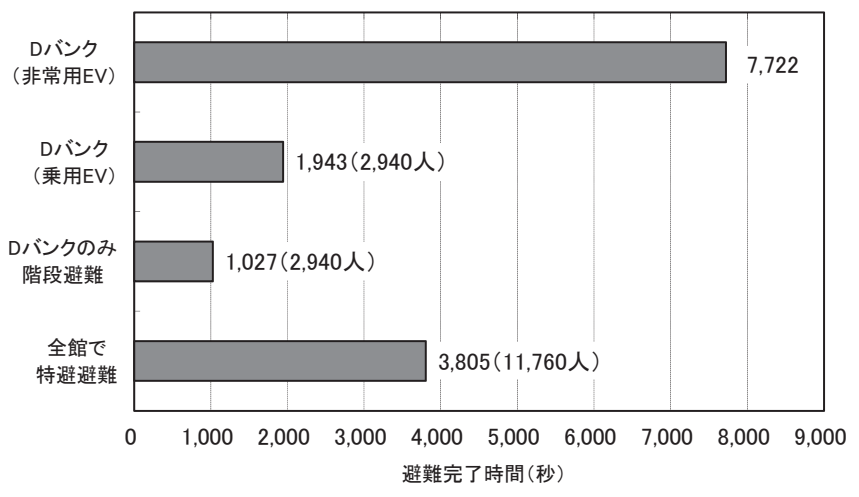

図 8 ケース 1（各避難手段による避難完了時間の比較）

このような結果となった理由として, 特別避難階段を利用した避 難では式 9 で示されるように, 階段内で滞留が発生する場合, 避難 完了時間は垂直移動時間では決定されず，単位時間あたり一定量で 避難者が避難階に到着する。一方, $\mathrm{EV}$ 利用避難の場合は 1 往復あ たりの垂直移動時間は階段利用避難よりも短いが， EV 利用者数が 多くなると往復回数が多くなり, さらに断続的に避難者が避難階に 到着するため, 結果として避難完了時間が階段利用避難よりも長く なったと考えられる。

\section{(2)ケース 2: 非常用 EV の運行方法による影響}

$\mathrm{D}$ バンクの最下階（44F）で火災が発生したと想定し，3 つの運 行方法別に避難完了時間を計算した。運行方法別の計算結果を図 9

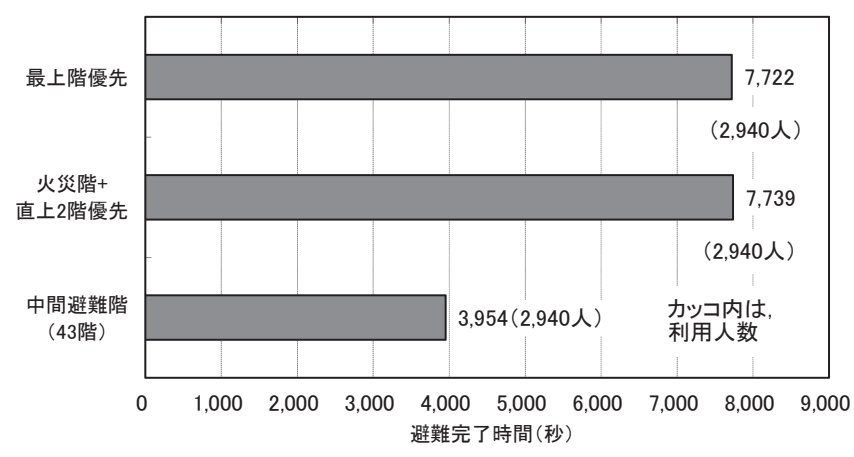

図 9 ケース 2(非常用 $\mathrm{EV}$ の運行方法による影響) 
に示す。なお, 中間避難階 $(43 \mathrm{~F})$ を考慮した運行方法では, 簡易 的に值を算出するために, $43 \mathrm{~F}$ までの $\mathrm{EV}$ 利用避難に要した時間と 階段利用時間を各々足し合わせた值とした。

計算の結果, 最上階優先の運行と火災階および直上 2 階優先の運 行による避難完了時間の差はほとんどみられなかった。この理由と して, 非常用 EV による避難完了時間は往復回数による影響が大き く, 各階に滞在する在館者数が変わらない場合, 運行パターンの影 響はほとんどないことが挙げられる。

また中間避難階を $43 \mathrm{~F}$ とし, そこから特別避難階段で避難した場 合には, 避難完了時間は 3,954 秒と上記 2 つの運行方法よりも約 3,780 秒（63 分）早い結果となった。このような状況となった理由 として, 非常用 EV の垂直移動距離が他の運行パターンよりも短い ため, 避難完了時間の短縮につながったことが挙げられる。

\section{(3)ケース 3 : 非常用 EV のサービス階の制限による影響}

非常用 $\mathrm{EV}$ の通過する階数を $1 \sim 13$ まで変化させた, スキップ運 転による全館避難完了時間への影響を検討した。計算結果を図 10 に示す。図 10 より，7 階層毎に停止階を設定した場合 (非常用 $\mathrm{EV}$ は 6 階層分を通過), 非常用 $\mathrm{EV}$ の利用人数の限定と移動時間の短 縮によって, $\mathrm{EV}$ 利用避難の方が階段避難よりも早く完了する結果 となった。

これより, 非常用 EVであっても, スキップ運転を行うことで移 動や乗降時間が短縮され, 非常用 $\mathrm{EV}$ 利用者は特別避難階段の避難 者より早く避難が完了寸ることも可能であることが分かった。

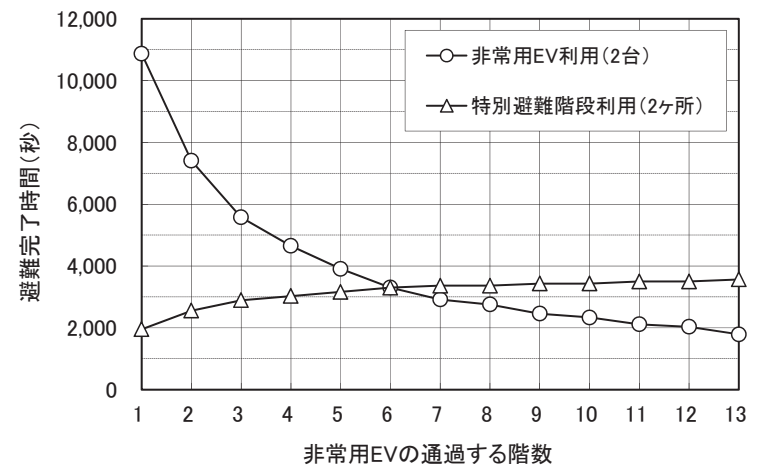

図 10 ケース 3 (非常用 $\mathrm{EV}$ のサービス階の制限による影響)

\section{(4)ケース 4: 非常用 EV の利用率による影響}

超高層建物での $\mathrm{EV}$ 利用避難において, より現実的な運行方法を 考え，2 台の非常用 $\mathrm{EV}$ の内， 1 台を避難用として利用，残り 1 台 は消防隊専用としての利用を想定し，特別避難階段による避難時間 との比較を行った。避難完了時間の比較結果を図 11 に示す。

図 11 より, $\mathrm{EV}$ 利用率を $0 \sim 100 \%$ に変化させた時, 非常用 $\mathrm{EV}$ による避難完了時間は直線的に増加し, 両者の避難完了時間が同等 となる $\mathrm{EV}$ 利用率は約 $8 \%$ となることが分かった。

これより, 定格速度が乗用 $\mathrm{EV}$ よりも遅い非常用 $\mathrm{EV}$ でサービス 階を全館（各階を停止階）とした場合であっても，各階での非常用 $\mathrm{EV}$ の利用を制約することで移動時間や乗降時間が短縮され，非常 用 $\mathrm{EV}$ を利用せずに特別避難階段で避難する場合より, 短い時間で の避難も可能であることが分かった。

これより, 超高層ビルの避難計画において, 健常者は特別避難階
段を利用して避難階まで移動し, 自力歩行困難者は介助者とともに 非常用 $\mathrm{EV}$ を利用寸る方法を採ることで，自力歩行困難者の迅速な 避難，階段内の混雑の解消が図られると考えられる。

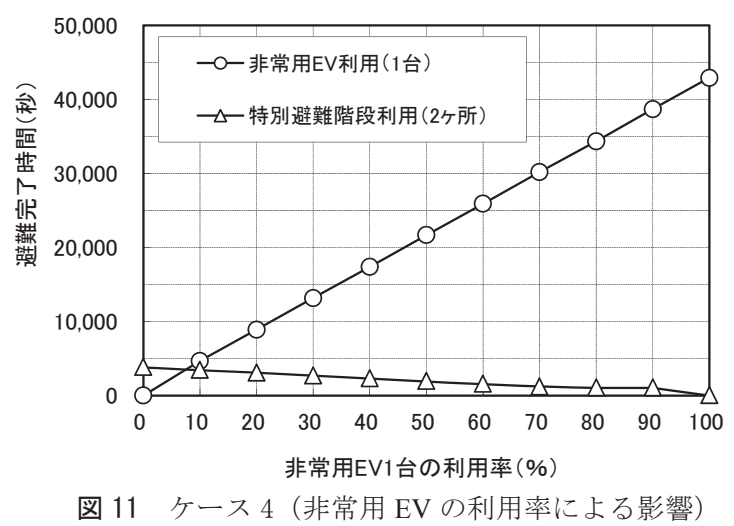

\section{3. まとめと今後の課題}

本研究では，超高層ビルにおける全館避難時に，階段のみを利用 する避難に比べて種々の $\mathrm{EV}$ を利用する避難のパターンがどの程度 有効であるかを明らかにすることを目的に，実存する超高層事務所 ビルを参考にケーススタディを行った。ケーススタディを実施する に当たり, $\mathrm{EV}$ 利用避難モデルの開発や $\mathrm{EV}$ 乗降時の流動係数に関 寸る調查を実施し, 避難時間の短縮という観点から，全館避難時に おける $\mathrm{EV}$ 利用のパターンについて考察した。以下にまとめを示す。

・EV 利用避難モデルにより，D バンクサービス階 $(44 \sim 57 \mathrm{~F})$ に 滞在する 2,940 人を対象に, 非常用 $\mathrm{EV}$, 乗用 $\mathrm{EV}$, 特別避難階段 の各々の方法による避難完了時間を比較した。計算の結果, 非常 用 $\mathrm{EV}$ を利用した場合の避難完了時間は他の避難方法よりも長く, 全館（A〜D バンク，滞在人数 11,760 人）を対象に特別避難階段 で避難させた時間のほぼ倍となった。また, 乗用 EV8 台による避 難であっても特別避難階段による避難の方が早い結果となり, 今 回のケースでは特別避難階段による避難が最も早い結果となった。 ・非常用 EV の通過する階数を 1 ～13 まで変化させた，スキップ運 転による全館避難完了時間への影響を検討した。その結果，今回 のケースでは非常用 EV の停止階を 7 階層毎に設定（非常用 EV は 6 階層分を通過して移動）することで移動時間や乗降時間が短 縮され, 非常用 $\mathrm{EV}$ 利用者は特別避難階段の避難者より早く避難 が完了することも可能であることが分かった。

・非常用 EV の 1 台を消防用, 残りの 1 台を避難用と想定し，特別 避難階段による全館避難時間との比較を行った。その結果, 今回 のケースでは，各階の非常用 $\mathrm{EV}$ の利用率を限定的に約 $8 \%$ 内に 収めれば，サービス階を全館（各階を停止階）とした場合でも， 非常用 EV を利用せずに特別避難階段で避難する場合より，短い 時間での避難も可能であることが分かった。

・今回のケーススタディを実施するに当たり, 乗用 $\mathrm{EV}$, 非常用 EV の両方を含めて $\mathrm{EV}$ の複数台運行を模擬する $\mathrm{EV}$ 利用避難モデル を開発した。このモデルにより, 超高層ビルにおける全館避難時 の $\mathrm{EV}$ 利用避難の様々な運行状況の予測が可能となった。

・ EV 扉の流動係数は, EVの内部は閉鎖空間であるため, 通常の建 物出入口扉の流動係数と異なると考えられるため, 実存寸る建物 
で $\mathrm{EV}$ 利用者の乗降調査を行い, 流動係数を測定した。その結果, 避難計画でよく利用される建物出入口扉における值 1.5 人 $/ \mathrm{m} / \mathrm{s}$ よ りも, 乗車時で 1.07 人 $/ \mathrm{m} / \mathrm{s}$, 降車時で 1.22 人 $/ \mathrm{m} / \mathrm{s}$ となり, いず れも避難計算で用いられる值よりも低いことが分かった。

また， $\mathrm{EV}$ 利用を考慮した全館避難に関する検討に関して，今後 の課題を以下に示す。

• $\mathrm{EV}$ 利用避難モデルに関して, 今回のケーススタディでは, 階毎 の避難誘導（避難開始の働きかけや， $\mathrm{EV}$ 利用者の振り分け，待 機者への指示等）が機能しているという前提の下で， EV 利用者 は EV ホールに整然と待機し, 順次乗り込むという状況を想定し た $\mathrm{EV}$ 利用避難モデルを構築した。しかし，こうした前提が成立 しない状況下においては，避難者の EV ホールへの到着遅れや各 階での EV の呼び出しタイミングが異なること等によって， EV の運行サイクルが乱れ，EV 利用避難時間へ影響を及ぼすこと等 が考えられる。より複雑な想定にも対応できるように, 今後更に 汎用性ある $\mathrm{EV}$ 利用避難モデルに向けた改良が課題である。

・ EV 利用避難の運用面に関して, 上記の課題とも関連するが, $\mathrm{EV}$ 利用避難に関しては, 運用上の条件, 例えば防災センター要員に よる非常用 $\mathrm{EV}$ 運転, 各階との情報伝達, 介助者の自力歩行困難 者への対応行動等, 様々な対応行動のシナリオが, 結果としての 避難時間を大きく左右する可能性がある。実効性を確保するため の方策等も含め, $\mathrm{EV}$ 利用避難の運用面をより明示的に考慮した ケーススタディの検討も，今後の課題である。

国際的には，中東やアジアでの超々高層ビルにおいて，EV を利 用した避難計画が実現している。日本での $\mathrm{EV}$ 利用避難の導入は, ハードだけでなくソフト面での対応等を十分に検討し，その導入に は慎重を期するべきと考えるが，筆者らは将来の高齢社会に伴う自 力歩行困難者の増加に対応するために, 非常用 $\mathrm{EV}$ の限定的利用を 含めた EV 利用避難に関する検討を進めていくべきと考える。

\section{謝辞}

三菱電機株式会社の田辺公男氏には，エレベーターの運行に関す る内容について，貴重なご意見やご助言を頂戴しました。ここに記 して謝意を表します。

\section{記号}

$L: \mathrm{EV}$ が出発階から目的階まで移動する垂直距離 $[\mathrm{m}], L_{s}$ : 階段利用避難にお ける最大垂直移動距離 $[\mathrm{m}] ， L_{2 F-\lambda F}$ ：2F から避難階（1F）までの垂直移動距離 $[\mathrm{m}], N_{e x i t}$ : 避難階段の $1 \mathrm{~F}$ 扉の流動係数 $[人 / \mathrm{m} / \mathrm{s}], N_{i n}: \mathrm{EV}$ 一流入する際の 流動係数 $[人 / \mathrm{m} / \mathrm{s}], N_{\text {out }}$ : $\mathrm{EV}$ から流出する際の流動係数 $[人 / \mathrm{m} / \mathrm{s}], N_{\text {stairs }}$ : 階 段内平均流動係数 $[$ 人 $/ \mathrm{m} / \mathrm{s}], P_{i}: i$ 階の階段利用避難人数 $[人], P_{i n}: \mathrm{EV}$ 一流 入する人数 $[$ 人 $], P_{\text {out }}: \mathrm{EV}$ から流出する人数 $[$ 人 $], t_{1}: \mathrm{EV}$ が加速段階におけ る移動時間 $[\mathrm{s}], t_{2}: \mathrm{EV}$ が定速段階における移動時間 $[\mathrm{s}], t_{3}: \mathrm{EV}$ が減速段 階における移動時間 $[\mathrm{s}], t_{\text {move }}: \mathrm{EV}$ が出発階から目的階まで移動する時間 $[\mathrm{s}]$, $t_{\text {flow_in }}: \mathrm{EV}$ 扉が開き $\mathrm{EV}$ 利用者が乗車して扉が閉まるまでの時間 $[\mathrm{s}], t_{\text {flow_out }}$ : $\mathrm{EV}$ 扉が開き $\mathrm{EV}$ 利用者が降車して扉が閉まるまでの時間 $[\mathrm{s}], t_{\text {open }}: \mathrm{EV}$ 扉の 開時間 $[\mathrm{s}], t_{c l o s e}: \mathrm{EV}$ 扉の閉時間 $[\mathrm{s}], t_{\text {stair }}$ : 階段利用の避難時間 $[\mathrm{s}], V_{\max }$ : $\mathrm{EV}$ の定格速度 $[\mathrm{m} / \mathrm{s}], V_{s}$ : 垂直移動速度 $[\mathrm{m} / \mathrm{s}], W_{D}: \mathrm{EV}$ の扉幅 $[\mathrm{m}], W_{\text {exit }}: 1 \mathrm{~F}$ 扉の有効出口幅 $[\mathrm{m}], W_{\text {stairs }}$ : 有効階段幅 $[\mathrm{m}], \alpha: \mathrm{EV}$ の加速度 $\left[\mathrm{m} / \mathrm{s}^{2}\right], \quad \beta$ : $\mathrm{EV}$ の減速度 $\left[\mathrm{m} / \mathrm{s}^{2}\right]$

\section{参考文献}

1）中野美奈，久保田勝明，海老原学，野竹宏彰，金子弘幸，大宮喜文：広島 基町高層住宅火災時における避難行動調査, 日本建築学会大会学術講演梗 概集 A-2，pp. 107-110，1997.7

2) 日本建築学会社会ニーズ対応推進委員会 : 避難安全のバリアフリーデザイ ン調査委員会公開委員会記録，2013.4

3) 東京消防庁: 高齢社会の到来を踏まえた高層建築物等における防火安全対 策のあり方，火災予防審議会人命安全対策部会答申，2013.4

4）萩原一郎：火災時等の非常時におけるエレベータ利用に関するワークショ ップ参加報告, 火災 Vol. 54 No. 3 (通巻 270 号), pp. 51-55, 2004

5）関澤 愛: 高層建物の火災時における全館避難とエレベータ利用避難につ いて, 月刊フェスク，2012.10

6）日本建築学会防火委員会：火災時のエレベータを利用した避難計画指針 (案), 2006.9

7）河合清司，小西正彦，岩田雅史，林和博，豊岡俊一郎，秋山誉一：高層住 宅を対象とした火災時のエレベーター利用避難方法，日本機械学会，技術 講演会講演論文集，2008

8）三浦龍二, 出利葉大輔, 金子裕良, 阿部 茂: 階段とエレベータを併用し たビルの避難シミュレーション，日本機械学会，技術講演会講演論文集， pp. 51-54, 2009. 1

9) Michael J.Kinsey, Edwin R. Galea and Peter J. Lawrence : INVESTIGATING THE USE OF ELEVATORS FOR HIGH-RISE BUILDING EVACUATION THROUGH COMPUTER SIMULATION, Human Behaviour in Fire Symposium , pp.85-96, 2009

10) Ai Sekizawa, Shinji Nakahama, Manabu Ebihara, Hiroaki Notake and Yuka Ikehata : Study on Feasibility of Evacuation by Elevators in a High-Rise Building, Workshop on the Use of Elevators in Fires and Other Emergencies, 2004.3

11）JOHN J.FRUIN : 歩行者の空間 理論とデザイン,p.70, 鹿島出版会, 1974.12

（2013年 7 月10日原稿受理，2013年 8 月14日採用決定） 